\title{
EMERGENCY RESPONSE PLAN GARUDA INDONESIA
}

\author{
Gian Prima Yogi., Aat Ruchiat, dan Yanti Setianti \\ Fakultas Ilmu Komunikasi Universitas Padjadjaran \\ E-mail: gprimayogi@gmail.com,
}

\begin{abstract}
ABSTRAK
Penelitian ini bertujuan untuk mengetahui latar belakang, proses implementasi, dan pemahaman manajemen terhadap Emergency Response Plan dalam penanganan krisis Garuda Indonesia. Metode yang digunakan pada penelitian ini adalah deskriptif kualitatif dengan Teori Reputasi. Teknik pengumpulan data penelitian ini dilakukan melalui observasi, wawancara, dan studi kepustakaan.Hasil penelitian ini menunjukkan bahwa latar belakang dibentuknya Emergency Response Plan adalah bisnis Garuda Indonesia yang sangat rentan terhadap krisis sehingga diperlukan manual penanganan krisis yang ditetapkan oleh perusahaan. Implementasinya adalah setiap karyawan Garuda Indonesia yang tergabung dalam Emergency Response Plan sudah mengetahui tugasnya masing-masing pada saat terjadi krisis, unit Corporate Communications secara garis besar bertugas untuk menjaga arus informasi tentang krisis yang terjadi kepada media massa dan keluarga penumpang. Pemahaman manajemen Garuda Indonesia terhadap Emergency Response Plan ditunjukkan dengan pemahaman karyawan terhadap tugas yang harus dilakukan setiap orang pada saat terjadi krisis.Kesimpulan dari penelitian ini adalah dari latar belakang, implementasi, dan pemahaman manajemen diperoleh fakta bahwa pelaksanaan Emergency Response Plan di Garuda Indonesia ini merupakan sistem yang sangat vital dalam menjaga kelancaran kegiatan bisnis Garuda Indonesia agar selalu dapat mengatasi krisis dengan baik.
\end{abstract}

\section{Kata kunci:}

\section{ABSTRACT}

The research aims to find out the background, implementation, and the comprehension of employee about Emergency Response Plan under crisis handling of Garuda Indonesia. The method used in this research in Descriptive Cualitative, with support of Reputation Theory. The data collection technique of the research is conducted through observation, interview, and literature review. The result of this research shows that the background formed the Emergency Response Plan is the business activity of Garuda Indonesia is so susceptible againts crisis so that the manual crisis handling set by the company is needed. The implementation is every employee of Garuda Indonesia and incorporated with Emergency Response Plan is understand the task of every employee when the crisis happened, the outline task of Corporate Communications unit is to mantained the information flow during the crisis to the media and passenger family. The employee comprehension about Emergency Response Plan shown by the comprehension of the employee about the task of each person during crisis. The conclusion of this research is from the background, implementation, and comprehension obtained by the fact that Emergency Response Plan implementation in Garuda Indonesia is very vital system in maintaining the flow of Garuda Indonesia business activity to always be handling the crisis well.

\section{Keyword:}




\section{PENDAHULUAN}

Krisis yang terjadi di dunia penerbangan tidak dapat dilepaskan dari tingginya resiko kecelakaan yang dihadapi oleh maskapai penerbangan dalam menjalani kegiatan operasional. Tingginya resiko terjadinya krisis tersebut harus dihadapi oleh maskapai penerbangan dengan persiapan yang matang untuk menghadapi krisis tersebut saat krisis benar-benar terjadi.

Pada tahun 2007 Garuda Indonesia mengalami kecelakaan fatal yaitu ketika pesawat GA-200 Boeing 737-400 tujuan Yogyakarta gagal mendarat di Bandara Adisujtipto dan terbakar di ujung runway 09 sebelah timur bandara yang menyebabkan 21 penumpang dan 1 awak kabin meninggal dunia. Kecelakaan tersebut merupakan salah satu krisis terbesar yang diterima oleh Garuda Indonesia semenjak berdirinya perusahaan tersebut pada 28 Desember 1949.

Krisis yang terjadi di dunia penerbangan tidak dapat dilepaskan dari tingginya resiko kecelakaan yang dihadapi oleh maskapai penerbangan dalam menjalani kegiatan operasional. Tingginya resiko terjadinya krisis tersebut harus dihadapi oleh maskapai penerbangan dengan persiapan yang matang untuk menghadapi krisis tersebut saat krisis benar-benar terjadi.

Pada tahun 2007 Garuda Indonesia mengalami kecelakaan fatal yaitu ketika pesawat GA-200 Boeing 737-400 tujuan Yogyakarta gagal mendarat di Bandara Adi sujtipto dan terbakar di ujung runway 09 sebelah timur bandara yang menyebabkan 21 penumpang dan 1 awak kabin meninggal dunia. Kecelakaan tersebut merupakan salah satu krisis terbesar yang diterima oleh Garuda Indonesia semenjak berdirinya perusahaan tersebut pada 28 Desember 1949.

Krisis terakhir yang menimpa Garuda Indonesia adalah pada saat Asosiasi Pilot Garuda (APG) melakukan mogok terbang pada tanggal 28 Juli 2011 yang disebabkan oleh besarnya perbedaan nominal gaji yang diterima pilot lokal dengan gaji pilot asing. Fakta-fakta diatas menunjukkan bahwa maskapai penerbangan dengan predikat bintang 4 versi Skytrax seperti Garuda Indonesia pun tidak luput dari berbagai macam permasalahan permasalahan yang melanda di dunia penerbangan.
Suatu hal yang sering terjadi dalam krisis citra sebuah perusahaan adalah krisis citra berkembang jauh lebih besar dari pada kenyataan yang terjadi di lapangan.Oleh karena itu penanganannya bukan terletak pada selesai tidaknya masalah krisis manajemen dalam perusahaan, tapi lebih jauh lagi, harus melihat lagi apakah citra perusahaan di mata publik sudah membaik atau belum. (Silih Agung Wasesa dan Jim Macnamara, 2010:84).

Pengambilan keputusan merupakan suatu proses manajemen, yang dimulai dengan perencanaan atau persiapan dan berakhir dengan pengendalian. Untuk mendapatkan hasil yang baik, pengambilan keputusan seharusnya mengikuti suatu tahapan yang sistermatis dan terkendali. Hasil suatu proses pengambilan keputusan sangat dipengaruhi bagaimana tahapan proses tersebut dilakukan. (Herjanto: 2007)

Berdasarkan regulasi penerbangan yang berlaku di seluruh dunia dan di Indonesia, Garuda Indonesia haruslah memenuhi berbagai macam regulasi dan peraturan yang ada dalam industri penerbangan, baik di Indonesia maupun dunia. Menyadari bahwa manajemen krisis merupakan hal yang dapat terjadi kapan saja, maka Garuda Indonesia membentuk sistem penanganan standar saat terjadi kecelakaan, yaitu Emergency Response Plan (ERP) yang akan berfungsi secara otomatis saat terjadi kecelakaan pesawat atau krisis manajemen lainnya.Pusat-pusat kegiatan maskapai yang difokuskan untuk menangani krisis kecelakaan pesawat Garuda Indonesia yang tergabung dalam Emergency Assesment Team (EAT) antara lain adalah Site Control Centre (SCC), GA Policy Group, Media Information Centre (MIC), Emergency Support Management Team (ESMT), Family Assistance Centre (FAC), Passenger Inquiry Centre (PIC), dan Aircraft Recovery Team (ART).

"Awal mulanya terbentuknya ERP merupakan untuk memenuhi peraturan yang dikeluarkan oleh International Civil Aviation Organization (ICAO) yang mengharuskan dibentuknya ERP dalam bentuk manual ERP. Pemerintah Indonesia sendiri yang tergabung dalam Civil Aviation Safety and Regulation (CASR) juga menyebutkan bahwa perusahaan yang akan bergerak di bidang airlines seharus- 
nya mempunyai ERP." Iksan Rosan, Senior Manager Public Relations Garuda Indonesia.

Semenjak awal berdirinya, Garuda Indonesia sudah memenuhi peraturan CASR 121.65 yang mengharuskan penerbangan di Indonesia harus memiliki ERP semenjak pertama kali berdiri.Tetapi, dalam penanganan krisis, menual ERP ini pada awalnya hanya berfungsi sebagian saja, belum di review, dan jobdesk masingmasing bagiannya juga belum jelas. Dengan adanya berbagai macam kecelakaan dan krisis yang melanda, maka Garuda Indonesia bertekad agar kedepannya perusahaan dapat lebih baik lagi dalam menangani krisis dengan menggunakan manual ERP yang sudah ada.

Selama periode 2010-2014 laju pertumbuhan penerbangan dalam negeri bisa mencapai 10 persen per tahun dengan jumlah penumpang domestik sebesar 38,9 juta orang dan menjadikan Indonesia sebagai pasar penerbangan domestik terbesar kesembilan di dunia dan pertumbuhan perjalanan internasional tercepat keenam di dunia dengan tingkat pertumbuhan sebesar 9,3 persen(International Air Transport Association).

Perkembangan dunia penerbangan di Indonesia tersebut juga tidak lepas dari beberapa kecelakaan pesawat yang pada akhirnya merugikan penumpang sebagai korban dan mengancam keselamatan para awak pesawat itu sendiri. Krisis yang terjadi dalam sebuah industri penerbangan merupakan hal yang harus ditangani dengan baik karena beberapa krisis terjadi dalam skala yang besar dan sangat berbahaya.Oleh karena itu, pentingnya sebuah Standar Operation Prochedure (SOP) dalam penanganan manajemen krisis untuk menjaga citra perusahaan dan memastikan kegitan perusahaan tetap dapat berjalan dengan lancar.

\section{METODE PENELITIAN}

\section{Pendekatan dan Jenis Penelitian}

Metode penelitian yang digunakan dalam penelitian ini adalah metode penelitian kualitatif. Peneliti yang melakukan penelitian kualitatif akan mencari bentuk dan perilaku manusia. Dan untuk menganalisa perilaku tersebut secara kualitatif, bukan hanya dengan menempatkannya secara sistematis atau bentukbentuk formal lainnya.Pendekatan ini tidak mencoba untuk mengeneralisasikan makna dari penelitian namun justru faktor kontekstual (perseorangan) yang menarik dari hasilnya.

Studi seperti ini nantianya akan membuktikan bahwa ilmu pengetahuan tidak mempunyai sifat objektif dan tetap melainkan interpretatif, didalam hal ini realitas sosial dibangun dari interaksi-interaksi sosial yang bersifat komunikasitf (Mulyana, 2003: 33)

Penelitian kualitatif adalah penelitian yang menggunakan latar alamiah dengan maksud menafsirkan fenomena yang terjadi dan dilakukan dengan jalan melibatkan berbagai metode yang ada (Denzin dan Lincoln, dalam Meleong, 2008:5).Dari segi pengertian ini, para penulis masi tetap mempersoalkan latar alamiah dengan maksud agar hasilnya dapat digunakan untuk penelitian kualitatif adalah berbagai macam metode penelitian.Dalam penelitian kualitatif, metode yang biasanya dimanfaatkan adalah wawancara, pengamatan, dan pemanfaatan dokumen.

Penelitian kualitatif adalah penelitian yang menggunakan pendekatan naturalistik untuk mencari dan menemukan pengertian dan pemahaman tentang fenomena dalam suatu latar yang berkonteks khusus. Pengertian ini hanya mempersoalkan doa aspek, yaitu pendekatan penelitian yang digunakan adalah naturalistik sedangkan upaya dan tujuannya adalah memahami suatu fenomena dalam suatu konteks khusus. Hal itu berarti tidak seluruh konteks dapatlah diteliti, tapi penelitian kualitatif itu harus dilakukan dalam suatu konteks yang khusus.

Penelitian kualitatif adalah penetian yang mengahasilkan prosedur analisis yang tidak menggunakan prosedur analisis statik atau cara kuantifikasi lainnya. Jelas bahwa pengertian ini mempertentangkan kualitatif dengan penelitian yang bernuansa kuantitatif, yaitu dengan menonjolkan bahwa usaha kuantifikasi apapun tidak perlu digunakan pada penelitian kualitatif. Belummmmmmmmmm DC

Pada dasarnya, penelitian kualitatif adalah upaya untu membangun pandangan yang diteliti dengan rinci, dibentuk dengan kata-kata, dan gambaran holistik yang rumit.Definisi ini lebih melihat perspektif emik dalam penelitian, yaitu memandang sesuatu upaya membangun pandangan subjek penelitian yang rinci, dibentuk dengan kata-kata, dan gambaran holistik yang rumit. Menurut Jane Richie, penelitian kualitatif adalah upaya untuk menyajikan dunia dari segi 
konsep, perilaku, persepsi, dan definisi disini dikemukakan tentang peranan penting dan apa yang seharusnya diteliti dengan konsep, perilaku, persepsi, dan persoalan tentang manusia yang diteliti (Meleong, 2008:5-6).

Metode penelitian deskriptif adalah suatu metode dalam meneliti status sekelompok manusia, suatu objek, suatu set kondisi, suatu sistem pemikiran, ataupun suatu kelas peristiwa pada masa sekarang. Tujuan dari penelitian deskriptif adalah untuk membuat deskripsi, gambaran atau lukisan secara sistematis, faktual dan akurat mengenai fakta-fakta, sifat, serta hubungan antar fenomena yang diselidiki. (Nazir, 2009:54).

Menurut Whitney (1960), metode desktiptif adalah pencarian fakta dengan interpretasi yang tepat. Penelitian deskriptif mempelajari masalahmasalah dalam masyarakat, serta tata cara yang berlaku dalam masyarakat serta situasi-situasi tertentu, termasuk tentang hubungan, kegiatankegiatan, sikap-sikap, pandangan-pandangan, serta proses-proses yang sedang berlangsung dan pengaruh-pengaruh dari suatu fenomena.

Pada metode deskriptif, peneliti bisa membandingkan fenomena-fenomena tertentu sehingga merupakan suatu studi komparatif. Adakalanya peneliti mengadakan klasifikasi, serta penelitian terhadap fenomena-fenomena dengan menetapkan suatu standar atau suatu norma tertentu, sehingga banyak ahli menamakan metode deskriptif ini dengan nama survei normatif. Dengan metode deskriptif ini juga diselidiki kedudukan fenomena atau faktor dan melihat hubungan antara suatu faktor dengan faktor yang lain. Oleh karena itu, metode deskriptif juga dinamakan studi kasus.

Metode deskriptif juga ingin mempelajari norma-norma atau standar-standar, sehingga penelitian deskriptif ini disebut juga dengan survei normatif. Dalam metode deskriptif dapat diteliti masalah normatif bersama-sama dengan masalah status dan sekaligus membuat perbandingan-perbandingan antarfenomena. Studi demikian dinamakan secara umum sebagai studi atau penelitian deskriptif. Perspektif waktu yang dijangkau dalam penelitian deskriptif adalah waktu sekarang, atau sekurang-kurangnya jangka waktu yang masih terjangkau dengan ingatan responden.

\section{HASIL DAN PEMBAHASAN}

Peneliti berupaya memaparkan hasil penelitian dan pembahasan mengenai Emergency Response Plan dalam penanganan krisis Garuda Indonesia, yang didalamnya terdapat latar belakang dibentuknya Emergency Response Plan, proses implementasi Emergency Response Plan, dan pemahaman karyawan Garuda Indonesia tentang Emergency Response Plan. Peneliti telah menggunakan pedoman wawancara untuk mempermudah dalam menggali informasi lebih jauh sesuai pendapat dan pandangan, berkaitan dengan pelaksanaan Emergency Response Plan dalam penanganan manajemen krisis Garuda Indonesia.

Emergency Response Plan atau biasa disingkatERPmerupakan salah satu organisasi dan program yang khusus menangani krisis yang dialami oleh Garuda Indonesia dengan tujuan agar dapat menyelesaikan krisis dengan cepat tanpa mengganggu kegiatan bisnis Garuda Indonesia secara keseluruhan.

\section{Latar BelakangDilaksanakannyaEmergency Response Plan dalam Penanganan Krisis Garuda Indonesia}

Garuda Indonesia adalah maskapai penerbangan pertama di Indonesia yang telah beroperasi semenjak tahun 1949 dan menjadi saksi sejarah perjuangan bangsa Indonesia dalam mempertahankan dan mengisi kemerdekaan. Sebagai maskapai penerbangan dengan konsep full service terkemuka di Indonesia, Garuda Indonesia selalu memberikan yang terbaik bagi setiap penumpangnya, mulai dari layanan, armada, hingga faktor keamanaan yang amat diperhatikan di setiap sektor kegiatan yang dilakukan oleh Garuda Indonesia.

Emergency Response Plan atau disingkat ERP merupakan salah satu panduan yang digunakan Garuda Indonesia setiap kali menangani krisis yang dihadapi.

"ERP adalah buku panduan atau buku manual dan juga organisasi dimana organisasi ini digunakan ketika masa krisis. ERP ini melibatkan banyak unit, bahwa beberapa unit yang terlibat itu akan menjadi organisasi khusus yang mengelola krisis ketika krisis itu terjadi. Di ERP ini ada berbagai macam 
organisasi. Organisasi ini ketika periode normal maka akan hibernate. Tapi ketika krisis terjadi, maka Operation Control Center (OCC) akan menyampaikan masa krisi dan organisasi ERP akan diaktifkan sehingga orang-orang yang terlibat di ERP akan aktif dan berkoordinasi pada masa krisis. Organisasi normal atau organisasi Garuda Indonesia secara besar akan difokuskan untuk mengelola industri yang bersifat normal dan dilepaskan dari hal-hal yang berbau krisis. Krisis akan ditangani oleh organisasi ERP."'

Kompleksnya kegiatan bisnis yang dilakukan Garuda Indonesia setiap hari membuat kemungkinan untuk terjadinya krisis sangatlah besar sehingga kebutuhan akan respon cepat pada setiap penanganan krisis menjadi hal yang sangat penting. Dengan langkah-langkah yang sudah diatur dengan jelas, setiap terjadi krisis Emergency Response Plan akan langsung diaktif-kan dan setiap orang dan unit yang terlibat dalam organisasi Emergency Response Plan ini sudah mengetahui tugas apa yang harus mereka lakukan untuk meredam krisis yang terjadi seperti dijelaskan oleh Bapak Ikhsan Rosan.

"Di ERP ini ada berbagai macam organisasi. Organisasi ini ketika periode normal maka akan hibernate. Tapi ketika krisis terjadi, maka Operation Control Center (OCC) akan menyampaikan masa krisi dan organisasi ERP akan diaktifkan sehingga orang-orang yang terlibat di ERP akan aktif dan berkoordinasi pada masa krisis. Organisasi normal atau organisasi Garuda Indonesia secara besar akan difokuskan untuk mengelola industri yang bersifat normal dan dilepaskan dari halhal yang berbau krisis. Krisis akan ditangani oleh organisasi ERP."2

Krusialnya fungsi Emergency Response Plan dalam bisnis Garuda Indonesia juga diucapkan oleh Ibu Diah Wiratni yang sudah 20 tahun bekerja di Garuda Indonesia. Menurut beliau, bisnis Garuda Indonesia adalah bisnis yang tidak pernah berhenti beroperasi dan sangat luas daerah operasinya sehingga kemungkinan untuk terjadinya krisis sangatlah besar dan tidak dapat diprediksi. Dengan adanya perencanaan

1 Ikhsan Rosan, wawancara 25/11/2013

2 Ikhsan Rosan, wawancara 25/11/2013 yang matang dalam menangani krisis melalui Emergency Response Plan, setiap krisis yang akan dan sudah terjadi dapat ditanggulangi dengan lebih baik agar krisis tersebut tidak menjalar ke kegiatan bisnis Garuda Indonesia secara keseluruhan.

"Garuda Indonesia adalah perusahaan penerbangan yang beroperasi setiap hari 24 jam, tidak hanya beroperasi di Indonesia, tetapi juga di seluruh dunia. Bisnis penerbangan merupakan bisnis yang sangat rentan terhadap krisis. Segala sesuatu dapat terjadi kapanpun, dimanapun, tanpa mengenal waktu maupun tempat. Karena itulah perusahaan mempunyai ERP (Emergency Respon Plan) yang merupakan buku panduan apabila terjadi situasi krisis, dan apa yang harus dilakukan untuk mengatasi krisis tersebut. Di dalam ERP sudah tercantum lengkap, dari seluruh unit, seluruh pihak-pihak yang berkepentingan di intern perusahaan, serta apa yang harus dilakukan apabila terjadi sesuatu."’3

Besarnya peluang terjadinya krisis dalam seluruh kegiatan bisnis Garuda Indonesia sudah disadari oleh karyawannya dengan menganggap krisis operasi yang berujung pada krisis citra itu harus ditanggapi dengan cepat dan dengan baik sehingga tidak memperngaruhi kegiatan Garuda Indonesia secara keseluruhan dan tidak berakibat buruk pada citra perusahaan. Pemahaman yang baik terhadap besarnya jumlah orang yang terlibat dan banyaknya jumlah kegiatan yang harus dilakukan untuk mendukung setiap penerbangan yang menjadi faktor utama besarnya peluang terjadinya krisis terlihat dari pernyataan Bapak Ikhsan Rosan selaku Senior Manager Public Relations Garuda Indonesia.

"Menurut saya penanganan krisis untuk bisnis seperti Garuda Indonesia ini sangat penting. Dari aspek komunikasi, kita bisa menaikan reputasi atau semakin menurutkan reputasi, tergantung bagaimana kita menangani situasi krisis tersebut. Jika kita mendapatkan krisis, namun kita mempunyai persiapan dan implementasi yang baik, serta dapat menanganinya dengan baik, maka akan menaikan reputasi perusahaan. Artinya, perusahaan kita cukup mampu mengatasi situasi-situasi krisis tersebut."4

3 Diah Wiratni, wawancara 5/12/2013

4 Ikhsan Rosan, wawancara 25/11/2013 
Pernyataan Bapak Ikhsan Rosan tersebut juga diamini oleh Ibu Diah Wiratni dan Ibu Sheila yang juga sudah memiliki pengalaman dalam melaksanakan Emergency Response Plan.

"Menurut saya penanganan krisis untuk bisnis seperti Garuda Indonesia ini sangat penting. Dari aspek komunikasi, kita bisa menaikan reputasi atau semakin menurutkan reputasi, tergantung bagaimana kita menangani situasi krisis tersebut. Jika kita mendapatkan krisis, namun kita mempunyai persiapan dan implementasi yang baik, serta dapat menanganinya dengan baik, maka akan menaikan reputasi perusahaan. Artinya, perusahaan kita cukup mampu mengatasi situasi-situasi krisis tersebut."

"Krisis adalah sesuatu yang tidak diinginkan, selalu ada peluang untuk terjadi, terutama di bisnis dengan ruang lingkup yang cukup besar dan melibatkan banyak orang. Misalnya dalam satu penerbangan Garuda, berapa banyak orang yang terlibat, mulai dari cabin crew, cockpit crew, crew darat, reservasi sebelum terbang, petugas check in, ketika sampai tujuan juga ada baggage handling. Jadi dengan keterlibatan banyak pihak, krisis dan trouble sangat mungkin sekali muncul. Tapi menurut saya, selama kita mempunyai pegangan, mengetahui prosedur yang benar, dan jujur ke konsumen bahwa terjadi sesuatu, kita sedang berusaha semaksimal mungkin mengatasi situasi yang terjadi, kita tetap mengutamakan safety dan security serta tetap mengutamakan service kepada penumpang, menurut saya itu menjadi suatu tantangan tersendiri. Kita tetap jadikan perhatian bahwa untuk kedepannya, maslaah yang pernah terjadi harus kita pelajari, dan sudah menjadi pengalaman suatu hal yang pernah kita tangani. ${ }^{\prime 6}$

Sebelum adanya Emergency Response Plan, sebenarnya Garuda Indonesia sudah memiliki sistem penanganan krisis yang dibentuk semenjak perusahaan ini berdiri karena hal tersebut merupakan salah satu syarat saat membentuk maskapai penerbangan. Namun, Emergency Response Plan ini adalah penyempurnaan dari sistem sebelumnya yang masih dianggap kurang maksimal dalam menangani 5 Diah Wiratni, wawancara 5/12/2013

6 Sheila Indira, wawancara 8/12/2013 krisis yang dialami Garuda Indonesia seperti dijelaskan oleh Bapak Ikhsan Rosan.

"Idealnya, setiap perusahaan penerbangan harus mempunyai ERP. Namun, ERP Garuda Indonesia mulai aktif sejak tahun 1998. Walaupun sebelumnya ada organisasi yang mirip dengan ERP, yang berada dibawah wilayah Direktorat Koperasi dan khusus mengelola krisis dari sisi operasional. Sejak 1998 ERP mulai intens dan dibuat ideal sehingga Garuda Indonesia comply dengan aturan internasional. ${ }^{7}$

Sebelum adanya penanganan krisis dengan Emergency Response Plan, penanganan krisis di Garuda Indonesia tidak terpusat menggunakan satu manual khusus yang dipahami oleh semua orang, tapi lebih tersebar kepada antar masingmasing unit yang ada di Garuda Indonesia, sehingga penanganan krisis dianggap kurang efektif dan arus informasi yang kurang cepat untuk diberitakan ke media massa yang dapat dilihat dalam hasil wawancara dengan Ibu Sheila Indira.

"Sebelum ada ERP, penangan krisis di Garuda yang pertama pasti unit inconcern dahulu, yaitu unit Direktorat Operasi (DO), karena saat itu cabin crew dan pilot masih menjadi satu di DO. Sekarang cabin crew dan pilot sudah terpisah. Cabin crew di direktoral pelayanan atau service (DS), sedangkan pilot di DO. Dahulu, kita mendapat kabar dari DO terlebih dahulu. Mulai dari memperkirakan apa kemungkinan yang sudah terjadi dan dampak-dampak apa yang terjadi. Sebagai Humas kita secara aktif mencari data. Sebenarnya mencari data ini tidak hanya dilakukan saat emergency, tetapi juga untuk segala case, seperti delay dan system down. Kita di bagian humas sudah memiliki prosedur dimana kita wajib mencari informasi dan data sebanyak-banyaknya dari unit terkait, yaitu unit operational, ground service, atau station-nya, di Jakarta maupun di luar. Kita mencari informasi dari pihak tersebut untuk dijadikan satu. terjadinya sesuatu akan membuat adanya kecenderungan media atau punlik untuk cepat bereaksi, karena itu jangan sampai kita sebagai pihak dalam, pihak Humas, tidak terinformasi. Secara proseduran pasti sudah

7 Ikhsan Rosan, wawancara 25/11/2013 
kita lakukan. Kita cek bagian scheduling, bagian operasional, apa yang terjadi. Misalnya pesawat delay. Delaynya sudah berapa lama, rutenya dari mana ke mana, keadaan penumpangnya seperti apa, kenapa delay, apakah karena alasan operasional atau tidak. Jika karena alas an operasional, kenapa pesawat rusak, bagian apa yang rusak, step apa yang sudah siambil, seperti apa service recovery kita ke penumpang, pesawat akan terbang jam berapa, kita harus sudah mengetahui semuanya."

Besarnya resiko terjadinya krisis di Garuda Indonesia adalah alasan pertama dibentuknya Emergency Response Plan di Garuda Indonesia. Pelaksanaan Emergency Response Plan ini ditujukan agar penanganan krisis Garuda Indonesia dapat dilakukan secara cepat dan tepat sehingga krisis tidak meluas dan mengganggu kinerja Garuda Indonesia secara lebih besar dan juga tidak mengganggu image Garuda Indonesia.

"Garuda Indonesia adalah perusahaan besar yang beroperasi 24 jam dan harus menjaga image perusahaan. ERP ini dimaksudkan supaya reputasi perusahaan terjaga. Sehingga apapun yang terjadi pada saat krisis bisa dikelola oleh kita dengan pengelolaan yang memenuhi standar internasional dan sifatnya profesional. Dalam hal ini supaya pemahaman masyarakat luas melihat Garuda memang perusahaan yang profesional yang mengacu pada standar internasional, sehingga dalam kaitan krisis, Garuda Indonesia mampu melaksanakan dan menangani krisis itu dengan sebaik-baiknya."

Alasan kedua yang membuat Garuda Indonesia akhirnya membentuk Emergency Response Plan adalah karena Garuda Indonesia harus taat pada peraturan pemerintah Indonesia dan peraturan penerbangan internasional yang dengan dilakukannya audit oleh organisasi penerbangan internasional seperti Federal Aviation Administration (FAA) dan juga International Air Transport Association (IATA) seperti dijelaskan oleh Ibu Diah Wiratni.

"Sebenarnya Garuda membentuk ERP itu mandatori. Selain karena Garuda Indonesia mengetahui karakter bisnisnya, Garuda Indonesia juga diaudit oleh auditor-auditor internasional, seperti FAA (Federal Aviation 8 Sheila Indira, wawancara 8/12/2013

9 Ikhsan Rosan, wawancara 25/11/2013
Administration) di Amerika, dan IATA (International Air Transport Association). Sebagai anggota IATA, Garuda Indonesia diaudit sehingga seluruh aspek mulai dari aspek operasional, aspek keuangan, terutama aspek keamanan. Mereka harus memastikan bahwa airline ini cukup aman dan memiliki segala persiapan bila terjadi sesuatu. Begitu juga dengan pihak asuransi. Premi untuk membayar asuransi sangat mahal karena klaimnya sangat besar, sehingga mereka menjadi ingin tahu dan tidak mau dirugikan, seperti mengenai kesiapan sudah sejauh mana, apa saja yang perlu disiapkan, bila terjadi sesuatu apakah perusahaan ini cukup mampu untuk mengatasi situasi krisis tersebut." 10

Berdasarkan penjelasan tiga narasumber diatas dapat dijelaskan bagaimana Garuda Indonesia memandang mengatasi krisis dengan cara yang tepat dan sistematis adalah sesuatu yang sangat penting. Mengingat bisnis Garuda Indonesia dilaksanakan 24 jam sehari dan berada di Indonesia dan diluar negeri, maka sudah seharusnya Garuda Indonesia menerapkan sistem penanganan krisis yang sangat rapi dan terorganisir seperti penerapan Emergency Response Plan ini.

Besarnya resiko terjadinya krisis sehingga membutuhkan sistem penanganan krisis seperti dijelaskan oleh Ibu Diah Wiratni yaitu karena Garuda Indonesia adalah perusahaan penerbangan yang beroperasi 24 jam, tidak hanya beroperasi di Indonesia tapi juga di seluruh dunia. Ibu Diah juga menjelaskan bahwa bisnis penerbangan merupakan bisnis yang sangat rentan terhadap krisis karena segala sesuatu dapat terjadi kapan pun dan dimana pun tanpa mengenal waktu dan tempat. Oleh karena itu Garuda Indonesia mempunyai Emergency Response Plan yang merupakan buku panduan bagi orang-orang yang terlibat didalamnya apabila terjadi krisis tentang apa yang harus dilakukan untuk mengatasi krisis tersebut.

\section{Proses Implementasi Emergency Response Plan dalam Penanganan Krisis Garuda Indonesia}

Ketika krisis benar-benar terjadi dan Emergency Response Plan dinyatakan diaktifkan oleh pimpinan perusahaan, maka sistem akan

10 Diah Wiratni, wawancara 5/12/2013 
langsung bekerja secara otomatis, setiap orang yang berada di dalam Emergency Response Plan akan langsung menuju pos kerjanya masingmasing karena mereka sudah paham tugas apa yang harus mereka lakukan saat terjadi krisis. Di unit Corporate Communications, pada saat Emergency Response Plan diaktifkan maka setiap orang yang tergabung didalam sistem akan langsung menuju semua pos Emergency Response Plan untuk kelancaran arus informasi untuk disampaikan kepada masyarakat melalui media massa. Namun, ada dua unit Emergency Response Plan yang menjadi fokus bagi unit Corporate Communications yaitu Media Information Center dan Family Assistance Center seperti yang dijelaskan oleh Bapak Ikhsan Rosan.

"Khusus unit kami, pengelolaannya adalah di MIC (Media Information Center). Jadi ketika OCC (Operation Control Center) menyatakan perusahaan krisis dan ERP diaktifkan, salah satu organisasi didalam ERP itu adalah MIC. Ketika kita diaktifkan, kita akan membentuk semacam pos dan orangorang yang terlibat didalamnya sudah aktif untuk melakukan pekerjaannya, disini kita mengolah informasi, kita ambil dan kita olah, kita analisis untuk kita sampaikan keluar. Penanganan krisis di unit Public Relations itu juga berkaitan dengan yang di website. Kita harus membuat website khusus yang bernama Dark Site karena ini sifatnya internasional, maka penanganan manajemen ERP itu juga bersifat internasional. Ada beberapa hal yang menjadi patokan kami, khususnya dalam hal krisis sendiri, melalui IOSA, dan kerjasama dengan maskapai-maskapai lain yang telah kami lakukan dan nanti 2014 kami juga akan bergabung dengan aliansi Skyteam, penanganan krisisnya juga harus comply dengan aturan yang sudah ditetapkan oleh Skyteam. Disini kita mengacu pada yang dinamakan dengan Manual Crisis, baik Crisis Communications Manual Garuda Indonesia maupun dari Skyteam dan maskapaimaskapai yang lainnya. Disini kita juga punya orang-orang seperti yang ditempatkan di OCC (Operation Control Center) untuk lalu lintas data ke MIC (Media Information Center), juga ada ke FAC (Family Assistance Center) dan beberapa unit yang disitu mutlak memerlukan orang dari kita untuk pengelolaan komunikasi dan data keluar." 11

11 Ikhsan Rosan, wawancara 20/12/2013
Arus informasi didalam sistem Emergency Response Plan menjadi fokus utama peran unit Corporate Communications karena sifatnya yang berfungsi sebagai sumber informasi bagi semua pihak yang berkepentingan pada saat sebuah krisis terjadi. Penempatan anggota dari Corporate Communications di setiap unit yang ada di ERP ditujukan untuk menjadi mata dan telinga bagi Media Information Center agar dapat mendapatkan data yang terbaru tentang krisis yang terjadi. Data ini juga bisa menjadi landasan bagi manajemen untuk menentukan tindakan apa yang harus dilakukan untuk mengatasi krisis yang sedang terjadi. Setelah data diolah oleh Media Information Center, data tersebut akan diberikan kepada manajemen dan diteruskan kepada media massa melalui press release dan juga keluarga penumpang yang diorganisir melalui Family Assistance Center (FAC).

Kegiatan unit Corporate Communications yang bertindak sebagai sumber informasi dapat dilihat dari pernyataan Ibu Sheila Indira yang berperan pada MIC pada saat Emergency Response Plan diaktifkan.

"KetikaERPdibuka, Garuda akanmembentuk Emergency Control Center (ECC). Di dalam ECC terdapat banyak pihak termasuk Humas. Kita berperan sebagai source of information. Kita berhubungan dengan banyak pihak. Kita mengolah informasi tersebut. Misalnya sampai pukul sekian sudah terjadi delay berapa banyak, pesawat dengan tujuan mana saja, dengan nomor penerbangan berapa saja, informasi-informasi ini akan menjadi database kita, dan kita akan update data-data ini ke unit-unit lain. Kurang lebih setiap orang di Humas mempunyai tugas yang sama jika ERP aktif."

Penjelasan yang kurang lebih sama juga diutarakan oleh Ibu Diah Wiratni tentang peran yang dilakukan pada saat Emergency Response Plan dilakukan. Pada saat Emergency Response Plan diaktifkan, Ibu Diah bertugas di bagian Family Assistance Center (FAC) yang bertugas sebagai posko informasi dan pusat data bagi seluruh keluarga korban pada saat terjadi krisis di Garuda Indonesia.

"Dalam aspek komunikasi, sebenarnya masing-masing sudah ada plotnya, dan memang harus diupdate juga. Jika ada per-

12 Sheila Indira, wawancara 20/12/2013 
gantian karyawan, maka harus disesuaikan lagi. Di dalam ERP terdapat contact Garuda Indonesia, nomor handphone dan nomor telepon kantor harus dapat dihubungi 24 jam. Berdasarkan manual ini, saya sebenarnya bekerja di bidang yang berhubungan dengan media. Jika terjadi krisis, kita sudah punya counterpart. Di corporate communications, kita sebagai pusat medianya. Informasi yang keluar adalah informasi yang kita dapat dari berbagai unit, seperti family assistant, operation control, dan yang ada di lapangan. Saya terkait dengan family assistant, yaitu yang berhubungan dengan keluarga penumpang, dan sebenarnya tidak hanya mengikat ke hal tersebut saja. Selama saya bekerja di Garuda Indonesia, Garuda Indonesia telah mengalami 3 krisis. Pertama adalah kecelakaan di Medan, kedua pendaratan di Bengawan Solo, dan terakhir di Yogyakarta. Yang paling besar dampaknya adalah di Medan."13

"Garuda Indonesia sudah menerapkan ERP untuk menangani krisis, sehingga saat krisis terjadi Garuda Indonesia dianggap sudah bisa menangani krisis dengan sangat baik dan malah Garuda Indonesia mendapatkan apresiasi dari orang luar yaitu mendapat IPRA Award tahun 2007 dan menjadi benchmark organisasi lain dalam penanganan manajemen krisis." 14

Ketika terjadi krisis dan manajemen mengaktifkan Emergency Response Plan, organisasi ERP ini secara otomatis langsung aktif dan langsung melakukan setiap tugas yang telah ditentukan pada setiap orang. Jelasnya tugas tiaptiap orang yang tergabung dalam Emergency Response Plan itulah yang membuat Garuda Indonesia mampun menanggapi krisis dengan cepat dan tepat seperti dijelaskan oleh Ibu Sheila.

"Jika terjadi krisis, setiap unit punya pekerjaan masing-masing. Jika sudah level corporate, maka kita akan membentuk ECC. Perlu tidaknya ECC ditentukan dari manajemen. Orang-orang yang terkait langsung menuju posnya masing-masing. Manajemennya dari DV (Corporate Safety) dan DP (Corporate Communication). Koordinasi antara 2 pihak. Selain itu ada 13 Diah Wiratni, wawancara 21/12/2013 14 Ikhsan Rosan, wawancara 20/12/2013
Ground Operation (OG), Operation Support (OS), dan Flight Operation. Semua itu bersinergi secara kesatuan apa yang mereka kerjakan dirangkum menjadi satu dan akan menjadi information centernya. Kita sudah mempunyai ERP versi corporate. Bahkan di ERP manual itu sudah jelas nama-nama orang dan nomor-nomor telefonnya, beserta jobdesk-nya." ${ }^{15}$

Tujuan dari mengaktifkan Emergency Response Plan ini adalah untuk mengisolir krisis yang sedang terjadi sehingga tidak mempengaruhi dan mengganggu kegiatan Garuda Indonesia secara keseluruhan.

"Jadi GarudaIndonesiamembentuk organisasi khusus yaitu ERP yang khusus menangani Garuda Indonesia di masa krisis yang meliputi peran mulai dari manajemen sampai staff paling bawah. Poin nya adalah organisasi normal tidak dibebankan oleh krisis, jadi ERP inilah organisasi khusus yang menangani ERP khususnya dari hal operasional dan hal lain, termasuk juga sisi komunikasinya. Direksi perannya tidak mutlak didalam ERP, jadi peran serta direksi diminta kapan saja saat diperlukan, jadi bukan ketika direksi namanya tercantum namanya didalam ERP maka ia akan lepas dari tugas normalnya sehari-hari. Supaya organisasi yang lain bisa bekerja secara normal, bisa tetap produktif, dan seluruh organisasi tidak terpengaruh pada krisis. Dalam hal ini diharapkan ketika krisis ditangani oleh ERP, maka diharapkan produktivitas, kreasi, dan kegiatan secara umum tidak terganggu sehingga ERP ini perlu kita implementasikan untuk menjaga produktivitas perusahaan tidak menurun dan reputasi perusahaan tetap baik." 16

Menurut Ibu Diah Wiratni, hal yang paling penting pada saat Garuda Indonesia mengaktifkan Emergency Response Plan adalah untuk memastikan penumpang mendapatkan penanganan terbaik pada saat terjadi krisis. Bagaimana bentuk penanganan krisis dan keselamatan penumpang merupakan dua hal utama yang menjadi concern Garuda Indonesia pada saat mengaktifkan Emergency Response Plan. Cara penyampaian informasi yang diberikan ke media massa melalui siaran pers, $15 \quad$ Sheila Indira, wawancara 20/12/2013

16 Ikhsan Rosan, wawancara 20/12/2013 
konferensi pers, dan informasi yang diberikan kepada keluarga penumpang pun harus baik dan jelas informasinya. Dengan adanya penanganan penumpang dan penyebarluasan informasi yang baik pada saat terjadi krisis, diharapkan image perusahaan tidak akan menjadi buruk di mata masyarakat luas.

"Harapan yang paling penting dengan adanya ERP di Garuda Indonesia adalah keselamatan penumpang dan bagaimana penanganannya apabila terjadi situasi krisis. Garuda Indonesia merupakan perusahaan jasa dan menyampaikan pelayanannya harus baik. Bila terjadi sesuatu, kita harus meyampaikan hal tersebut dengan baik. Keselamatan penumpang adalah hal yang paling diutamakan. Apapun yang kita lakukan adalah untuk keselamatan penumpang. Image yang bagus hanyalah hasil dari penanganan situasi dengan baik, yang penting adalah proses penanganannya."'17

MenurutNova(2009: 140), masalah utama dalam krisis komunikasi adalah memastikan bahwa fakta itu benar dan menyebarluaskannya sesuai dengan time frame. Jika organisasi tidak dapat menyebarkan fakta dengan cara yang tepat pada waktunya, media akan berspekulasi dengan caranya sendiri. Perencanaan krisis dapat dilakukan dengan membentuk tim yang bertanggung jawab dalam mengelola krisis. Masing-masing orang didalam tim memiliki tanggung jawab spesifik dengan tugas yang jelas. Lebih dari itu, kontak akan dibuat agar komunikasi bisa terjadi dengan cara dan waktu yang tepat, tanpa perlu mencari tahu siapa yang harus dihubungi dan bagaimana menghubungi mereka disaar krisis. Perencanaan krisis yang baik akan membantu PR dalam memahami bagaimana cara mengelola krisis berikut langkah-langkahnya. Perencanaan krisis seperti membuat suatu petunjuk untuk pembangunan model pesawat terbang. Tanpa petunjuk, tidak mungkin memasang model kapal terbang dengan semestinya. Cara apapun akan ditempuh, perencanaan krisis PR adalah gagasan luar biasa bagi perusahaan manapun. Elemen penting yang kadang-kadang diabaikan adalah menguji business continuity plan, yaitu dengan melakukan simulasi-simulasi rencana bisnis yang suda ada. Perusahaan yang memiliki

17 Diah Wiratni, wawancara 21/12/2013 business conitnuity plan akan berda pada posisi yang lebih baik untuk meminimalkan dampak krisis dalam bisnis dan kondisi keuangannya.

Dua puluh tujuh menit setelah kecelakaan penerbangan GA-200, Garuda Indonesia segera menayangkan informasi penerbangan khusus dan menampilkan nomor kontak khusus untuk keluarga korban. Di hari yang sama pukul 14.00 WIB, informasi mengenai status penumpang GA-200 juga dipublikasikan di website Garuda Indonesia. VP Corporate Communication, Pujobroto, pada hari itu juga segera melakukan siaran pers. Bapak Pujobroto menjelaskan bahwa pesawat jenis Boeing 737-400 tersebut sudah menjalani perawatan sesuai regulasi dan standar internasional. Pesawat buatan tahun 1992 itu sudah melakukan $A$ Check, $C$ Check, dan $D$ Check. Perawatan $A$ Check adalah perawatan pesawat yang jam terbangnya antara 400-4.500 jam. Setelah mencapai 4.500 jam terbang maka dilakukan $C$ Check. Setelah $C$ Check dilakukan, jam terbang dihitung ulang untuk kemudian dilakukan $A$ Check kembali. Jika total jam terbang sudah mencapai 10 ribu jam, barulah dilakukan $D$ Check. Pesawat uang bergabung dengan Garuda Indonesia sejak 10 Oktober 2002 itu telah menjalani semua cek tersebut dengan baik. Presiden Direktur Garuda Indonesia, Bapak Emirsyah Satar, terjun langsung melakukan penanganan kecelakaan dan menjelaskan pada pers, melalui stasiun televisi, radio, koran, dan berusaha meredam persoalan dengan meminta maaf, berempati, dan berusaha menyampaikan informasi yang telah beliau ketahui sambil menunggu hasil penyidikan lanjutan akan kasus tersebut. Penanganan korban dan keluarga korban juga dilakukan secara maksimal, mulai dari penerbangan khusus keluarga korban, biaya simpati, dan pembayaran asuransi kepada ahli waris korban.

\section{Pemahaman Manajemen Terhadap Pelak- sanaan Emergency Response Plan dalam Penanganan Krisis Garuda Indonesia}

Pelaksanaan penanganan krisis Garuda Indonesia menuntut kesamaan pemahaman seluruh pihak yang terlibat untuk menciptakan penanganan krisis yang cepat dan tepat sesuai yang diharapkan. Kesamaan pemahaman dari seluruh manajemen di semua unit di Garuda Indonesia ini didapatkan dengan melakukan simulasi, pelatihan, dan pelaksanaan Emergency 
Response Plan secara berkala. Pemahaman yang dimaksudkan tidak hanya pemahaman tentang tugas masing-masing orang pada saat mengatasi krisis, tapi juga pemahaman tentang bagaimana seluruh manajemen Garuda Indonesia memandang bagaimana menghadapi krisis yang terjadi.

Ketika menempatkan orang-orang yang akan mengisi posisi pada Emergency Response Plan, Garuda Indonesia tidak menerapkan tes atau seleksi untuk mengisi posisi tersebut. Manajemen lebih memilih untuk menempatkan orang-orang yang memang sudah terbiasa melakukan suatu jenis pekerjaan untuk ditempatkan di posisi dengan tugas kerja yang hampir sama di Emergency Response Plan. Terlihat bagaimana manajemen mempercayai kualitas karyawannya untuk mengisi posisis tersebut tanpa harus mengikuti tes atau seleksi seperti dijelaskan oleh Bapak Ikhsan Rosan.

"Kalau dari sisi unit Public Relations yang masuk kedalam MIC, setengah dari unit ini masuk kedalam ERP mengacu pada tugas keseharian masing-masing. Kita menganggap semua karyawan itu sudah capable dalam bidangnya masing-masing, sehingga kita menunjuk orang yang masuk kedalam ERP bukan pada kapabilitas, tapi lebih kepada tugas dan fungsi masing-masing. Khususnya di MIC itu memang secara umum kita yang berkaitan dengan komunikasi baik eksternal maupun internal kita terlibat secara full dalam penugasan ERP."'18

Senada dengan pernyataan Bapak Ikhsan, Ibu Diah Wiratni juga menyatakan bahwa tergabung didalam Emergency Response Plan merupakan bagian dari pekerjaan karena pekerjaan yang dilakukan di Emergency Response Plan hampir sebagian besar merupakan pekerjaan yang dilakukan sehari-hari.

"Ada organisasi khusus pada ERP. Hampir sebagian besar karyawan merupakan bagian dari organisasi tersebut karena kita bukan suatu unit yang besar. Kita merupakan unit kecil namun sangat sentral karena kita berhubungan dengan pihak ketiga. Kita dapat disebut sebagai corong perusahaan. Jika ada sesuatu, kita yang menyampaikannya keluar, sehingga kita harus benar-benar memastikan keakuratan data.Terdapat pelatihan ERP

18 Ikhsan Rosan, wawancara 24/12/2013 yang berupa simulasi. Tergabung di ERP merupakan bagian dari pekerjaan. Pada saat ada karyawan baru, atau ada karyawan yang keluar, kita harus selalu update. Mau tidak mau karyawan baru juga harus ikut terlibat, harus mengetahui manual ERP. Terutama di humas, seluruh karyawan harus mengetahuinya." 19

"ERP dibentuk dengan proses yang cukup lama, dengan pembahasan yang cukup mandalam, dan meluas antar beberapa unit, antaranya adalah DV dan DP. DV sebagai person in charge dari ERP. Ada beberapa poin tugas yang memang sudah ditentukan dari ERP. Hampir seluruhnya melibatkan DV, DP, dan operasi. Memang ketika pembahasan kita sudah paham peranan-peranan kita. Fungsifungsi akan di break down lagi. Ada yang fungsinya di on site, ada yang di media center, ada yang di ECC. Semua sudah dalam satu flow yang sudah sangat jelas dan semua orang sudah mengetahui fungsinya masing-masing. Pemilihan orang-orang yang tercantum dalam ERP ditentukan oleh intern. Kita sebagai tim Humas yang menentukan kira-kira siapa yang mempunyai kemampuan. Tidak ada tes. Kita semua diharuskan ikut dalam semacam simulasi." ${ }^{20}$

Setelah setiap orang mengetahui tugas mereka masing-masing, tentu diperlukan penyamarataan informasi dan pemahaman pada setiap orang yang terlibat di dalam Emergency Response Plan ini. Penyamarataan informasi ini dimaksudkan agar setiap orang yang terlibat di dalam sistem memiliki pemahaman yang sama pada saat menangani krisis. Fungsi lainnya dari penyamarataan informasi ini adalah agar seluruh sistem memiliki informasi yang sama dan selalu terbarukan untuk menciptakan satu pemahaman dan pengetahuan di Emergency Response Plan saat menangani krisis.

"Penyamarataan informasi tentang update ERP bersumber dari DV. Kita termasuk dalam IATA, banyak kebijakan-kebijakan yang terkait dengan keamanan dan lain-lain, akan langsung berhubungan dengan DV. Biasanya akan ada informasi dari DV bahwa ada ERP yang perlu disempurnakan, diganti, atau diupdate. Kita mengacu pada pihak 19 Diah Wiratni, wawancara 24/12/2013 20 Sheila Indira, wawancara 24/12/2013 
yang berkewajiban concern mengenai hal itu. Jika tidak perlu ada yang diganti, maka kita mengikuti saja." ${ }^{21}$

Penyamarataan informasi tidak hanya dilakukan pada sistem kerja Emergency Response Plan yang berasal dari IATA dan FAA saja. Penyamarataan informasi juga sangat dibutuhkan ketika Garuda Indonesia mengalami krisis, sehingga diperlukan arus informasi yang cepat dan merata disemua unit untuk memastikan Emergency Response Plan dapat mengatasi krisis yang terjadi dengan cepat dan tepat. Walaupun penyamarataan informasi terbaru tentang krisis yang terjadi sangat diperlukan di seluruh unit Emergency Response Plan, namun untuk arus informasi dari perusahaan ke luar harus dilakukan oleh spokeperson yang memang sudah ditunjuk oleh perusahaan atau direksi. Setiap informasi, verbal maupun non verbal, yang akan disampaikan oleh spokeperson berasal dari informasi terbaru dari krisis yang telah diolah oleh Public Relations Garuda Indonesia. Hal ini dilakukan untuk menjaga agar informasi tentang krisis yang terjadi tidak simpang siur di media massa dan masyarakat.

"Untuk penyamarataan informasi update ERP, kita harus berusaha mencari tahu, dan mencari informasi yang benar. Halhal tersebut menjadi bekal kita untuk menjadikannya informasi yang layak untuk dipublish ke luar. Kita tidak dapat sembarang bicara ke media. Terutama jika terjadi situasi krisis, biasanya harus ke BOD. Direksi yang mempunyai kewenangan untuk bicara, atau orang yang ditunjuk oleh perusahaan. Kalau semua karyawan bicara ke media, informasinya dapat menjadi tidak jelas. Spokeperson biasanya adalah orang yang jabatannya paling tinggi, yaitu Pak Pujobroto. Sedangkan Pak Emir adalah pimpinan tertinggi di Garudak ita biasanya memberikan saran, kapan Pak Emir (CEO) yang bicara, dan kapan Pak Pujobroto yang bicara. Namun untuk pernyataan yang keluar pertama kali sebaiknya dari direksi." ${ }^{22}$

Garuda Indonesia sudah memiliki program untuk memaksimalkan penyamarataan informasi di semua orang yang terlibat di dalam Emergency Response Plan. Program-program 21 Sheila Indira, wawancara 24/12/2013 22 Diah Wiratni, wawancara 24/12/2013 ini ada yang berasal dari internal Garuda Indonesia sendiri dan ada juga yang berasal dari pelatihan yang dilaksanakan bukan oleh Garuda Indonesia seperti yang dijelaskan oleh Bapak Ikhsan Rosan.

"Sebenarnya kita sudah membuat beberapa program, seperti setiap orang itu sudah punya manual krisis komunikasi sendiri, harus sudah dibaca, sudah paham, dan ada juga simulasi yang dilakukan di unit Corporate Safety (DV) setiap 6 bulan untuk membuat setiap orang itu memiliki awareness alert yang sama dari setiap unit, mereka sudah tahu apa yang harus dilakukan, karena krisis itu tentang kecepatan, jadi tidak punya waktu lagi untuk membaca manual, otomatis sudah menjadi yang alami ketika krisis sudah switch in untuk melaksanakan ERP. Yang kedua juga ada semacam kursus atau workshop diluar simulasi yang dilakukan Garuda Indonesia untuk mendapatkan update terbaru tentang penanganan krisis. ${ }^{.23}$

Menjaga sesuatu biasanya lebih susah daripada mendapatkannya. Untuk menjaga pemahaman orang-orang yang terlibat di dalam Emergency Response Plan, Garuda Indonesia secara berkala mengadakan simulasi krisis yang bertujuan untuk menjaga pemahaman, pengetahuan, dan flow kerja pada saat menangani krisis yang bisa terjadi kapan pun.

Simulasi ini juga dilakukan agar semua orang yang terlibat di dalam Emergency Response Plan selalu aware akan besarnya kemungkinan terjadinya krisis dan selalu siap untuk mengatasi krisis tersebut seperti yang dijelaskan oleh Ibu Diah Wiratni.

"Untuk membuat karyawan aware terhadap ERP, biasanya people manager yang mensosialisasikannya, misalnya senior manager meneruskan ke bawahnya. Setiap unit pasti ada ERP. Bagian yang mengupdate ERP secara keseluruhan adalah DV. Karena itulah DV rutin mengadakan workshop atau yang lainnya supaya karyawan tetap aware terhadap ERP."24

Melalui wawancara mendalam ini juga, penulis menarik kasimpulan bahwa ketiga narasumber juga sudah sangat paham tentang tugas-tugas yang harus mereka lakukan pada saat 23 Ikhsan Rosan, wawancara 24/12/2013 24 Diah Wiratni, wawancara 24/12/2013 
Emergency Response Plan diaktifkan. Ketiga narasumber dapat menjelaskan tugas-tugas yang harus mereka lakukan dan bagaimana sistem kerja dengan unit lain di Garuda Indonesia pada saat Emergency Response Plan diaktifkan.

\section{SIMPULAN}

Simpulan dari penelitian tentang Emergency Response Plan Garuda Indonesia ini adalah:

1. Emergency Response Plan merupakan sistem yang sangat dibutuhkan oleh Garuda Indonesia untuk mengatasi krisis. Pembentukan Emergency Response Plan berangkat dari kebutuhan Garuda Indonesia pada sistem penanganan krisis yang sistematis karena bisnis Garuda Indonesia yang sangat rentan terhadap krisis.

2. Unit Corporate Communications Garuda Indonesia memiliki peran sentral sebagai penggali, pengolah, dan penyalur informasi pada saat terjadi krisis. Arus informasi ini sangat diperlukan oleh Garuda Indonesia sebagai dasar tindakan apa yang harus dilakukan untuk mengatasi krisis dan apa yang harus disampaikan kepada masyarakat melalui media massa.

3. Karyawan Garuda Indonesia yang tergabung di dalam Emergency Response Plan memahami krisis dan bagaimana cara mengatasi krisis. Karyawan Garuda Indonesia yang tergabung di dalam Emergency Response Plan juga memiliki pemahaman yang baik tentang Emergency Response Plan pada saat penanganan krisis sedang dilakukan.

\section{Saran}

Menurut peneliti, pelaksanaan Emergency Response Plan sebagai sistem penanganan krisis yang dilakukan oleh Garuda Indonesia sudah sangat baik. Dengan memiliki Emergency Response Plan ini Garuda Indonesia menjadi jauh lebih siap dalam menghadapi kemungkinankemungkinan krisis yang akan timbul dari bisnis yang mereka jalani. Saran pertama dari peneliti adalah agar Garuda Indonsia dapat meningkatkan intensitas simulasi yang dilakukan agar semua orang yang terlibat di dalam Emergency Response Plan bisa tetap aware dengan adanya krisis. Saran kedua adalah agar Garuda Indonesia bisa terus menambahkan bentuk-bentuk krisis yang ada manual penanganan krisisnya di dalam Emergency Response Plan, sehingga Garuda Indonesia akan menjadi semakin siap untuk menghadapi berbagai macam bentuk krisis.

\section{DAFTAR PUSTAKA}

Mulyana, Deddy. 2008. Metodologi Penelitian Kualitatif Paradigma Baru Ilmu Komunikasi dan Ilmu Soisal Lainnya. Bandung: Remaja Rosdakarya.

Nazir, Moh. 2009. Metode Penelitian. Jakarta: Penerbit Ghalia Indonesia.

Nova, Firsan. 2009. Crisis Public Relations: Bagaimana PR Menangani Krisis Perusahaan. Jakarta: Grasindo. 